\title{
SLAMF6 wt Allele
}

National Cancer Institute

\section{Source}

National Cancer Institute. SLAMF6 wt Allele. NCI Thesaurus. Code C105056.

Human SLAMF6 wild-type allele is located in the vicinity of $1 \mathrm{q} 23.2$ and is approximately 38 $\mathrm{kb}$ in length. This allele, which encodes SLAM family member 6 protein, plays a role as a coreceptor in natural killer cell activation. 